\title{
Late Quaternary glaciation of Tibet and the bordering mountains: a review
}

\author{
FRANK LEHMKUHL AND LEWIS A. OWEN
}

BOREAS

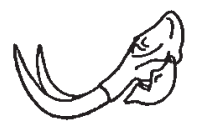

Lehmkuhl, F. \& Owen, L. A. 2005 (May): Late Quaternary glaciation of Tibet and the bordering mountains: a review. Boreas, Vol. 34, pp. 87-100. Oslo. ISSN 0300-9483.

Abundant glacial geologic evidence present throughout Tibet and the bordering mountains shows that glaciers have oscillated many times throughout the late Quaternary. Yet the timing and extent of glacial advances is still highly debated. Recent studies, however, suggest that glaciation was most extensive prior to the last glacial cycle. Furthermore, these studies show that in many regions of Tibet and the Himalaya glaciation was generally more extensive during the earlier part of the last glacial cycle and was limited in extent during the global Last Glacial Maximum (marine oxygen isotope stage 2). Holocene glacial advances were also limited in extent, with glaciers advancing just a few kilometers from their present ice margins. In the monsoon-influenced regions, glaciation appears to be strongly controlled by changes in insolation that govern the geographical extent of the monsoon and consequently precipitation distribution. Monsoonal precipitation distribution strongly influences glacier mass balances, allowing glaciers in high altitude regions to advance during times of increased precipitation, which are associated with insolation maxima during glacial times. Furthermore, there are strong topographic controls on glaciation, particular in regions where there are rainshadow effects. It is likely that glaciers, influenced by the different climatic systems, behaved differently at different times. However, more detailed geomorphic and geochronological studies are needed to fully explore regional variations. Changes in glacial ice volume in Tibet and the bordering mountains were relatively small after the global LGM as compared to the Northern Hemisphere ice sheets. It is therefore unlikely that meltwater draining from Tibet and the bordering mountains during the Lateglacial and early Holocene would have been sufficient to affect oceanic circulation. However, changes in surface albedo may have influenced the dynamics of monsoonal systems and this may have important implications for global climate change. Drainage development, including lake level changes on the Tibetan plateau and adjacent regions has been strongly controlled by climatic oscillations on centennial, decadal and especially millennial timescales. Since the Little Ice Age, and particularly during this century, glaciers have been progressively retreating. This pattern is likely to continue throughout the 21 st century, exacerbated by human-induced global warming.

Frank Lehmkuhl (e-mail: Flehmkuhl@geo.rwth-aachen.de), Department of Geography, RWTH Aachen, Templergraben 55, D-52062 Aachen, Germany; Lewis A. Owen (e-mail: Lewis.Owen@uc.edu), Department of Geology, University of Cincinnati, Cincinnati, OH 45221-0013, USA; received 1st September 2003, accepted 17th November 2004.
The Tibetan Plateau and bordering mountains are the greatest glaciated tracks outside the Polar Region. They have a profound influence on regional and global atmospheric circulation and are therefore important for our understanding the dynamics of global environmental change (Ruddiman \& Kutzbach 1989; Molnar \& England 1990; Prell \& Kutzbach 1992; Owen et al. 2002d). Changes in glaciation and hydrology in Tibet and the bordering mountains throughout the late Quaternary may have altered the input of fresh water into the seas and oceans adjacent to the Asian continent. This in turn could have had a major impact on ocean circulation and global climate, an impact analogous to effects of the melting of the Laurentide Ice Sheet on North Atlantic oceanic circulation towards the end of the Last Glacial (cf. Broecker et al. 1989). In particular, glaciation throughout Tibet and the bordering mountains was probably far more extensive during the Late Pleistocene than at present, and it is possible that when glaciers began to retreat during the termination of the last glacial cycle substantial amounts of meltwater produced new drainage systems feeding into the adjacent seas. Yet, despite its importance, the timing and extent of glacial advances are still highly debated. To investigate links between glaciation, hydrology and environmental change in the high mountains of Central Asia, and the possible relationship with global climate change, this article aims to synthesis new research and the current knowledge on the late Quaternary glaciation of Tibet and the bordering mountains (Fig. 1).

This paper extends work presented in a comprehensive bibliography produced by Barnard \& Owen (2000), research papers (Owen \& Lehmkuhl 2000; Owen \& Zhou 2002) and summaries of the Global Mapping Project of INQUA on the glacial geology in central Asia (Ehlers \& Gibbard 2004). We stress the importance of developing a modern framework for the geomorphic and sedimentological analysis of glaciogenic sediments and landforms in high mountain environments for the accurate reconstruction of former glaciers. We highlight the problems of dating glacial

DOI: 10.1080/03009480510012908 C 2005 Taylor \& Francis 


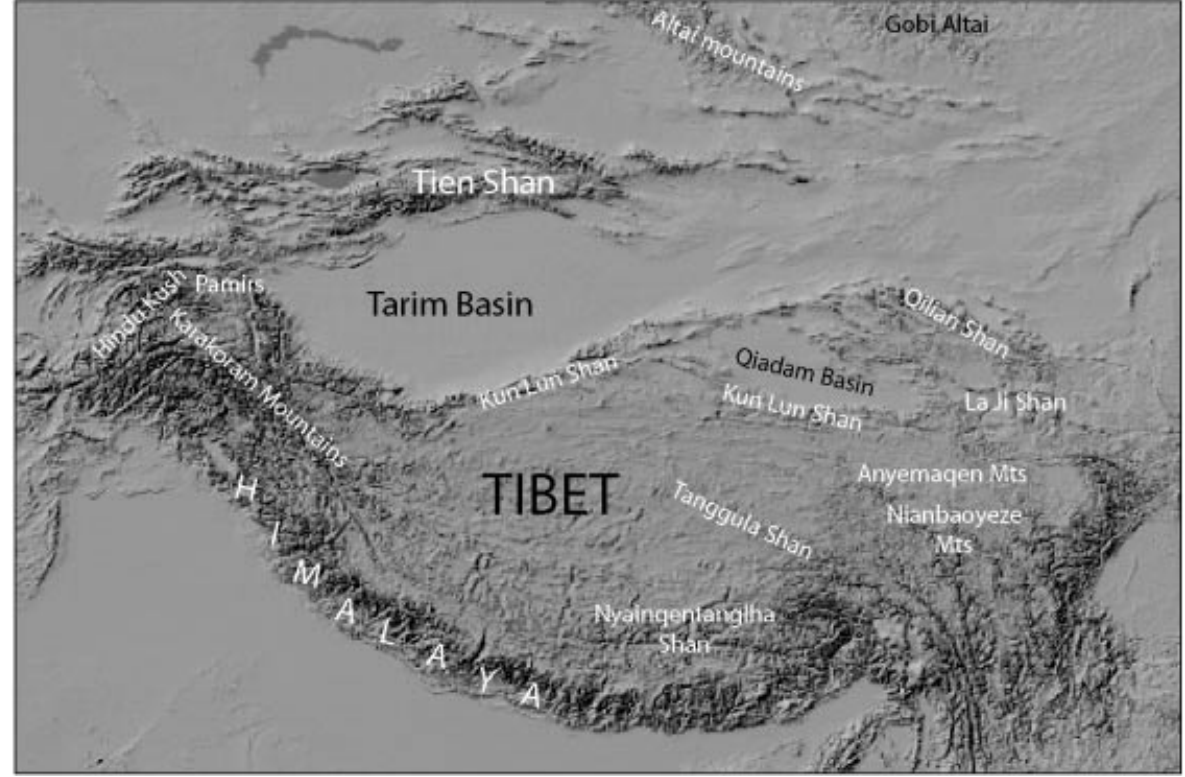

Fig. 1. The extent of the region covered by this article. successions and encourage programmes for numerical dating in critical regions, as suggested by Benn \& Owen (2002). Furthermore, we emphasis the problems of using and calculating equilibrium-line altitudes (ELAs) as a means of quantifying glaciation and reiterate the recommendations provided to help quantify the degree of glaciation using reconstructions of former glacier extent presented by Benn \& Lehmkuhl (2000), Benn et al. (2005), Owen \& Benn (2005). We also highlight the usefulness of other palaeoclimate proxy data, such as the loess, lacustrine, fluvial and palaeobotanical records. In particular, we highlight the importance of the lake record, especially because, during the Pleistocene, lakes in the western Tibetan Plateau covered an area four times the present extent $\left(\sim 80000 \mathrm{~km}^{2}\right.$, vs. $\sim 20000 \mathrm{~km}^{2}$; Lehmkuhl \& Haselein 2000). Such lake level changes could have profound effects on regional climate because of changes in albedo and precipitation.

\section{Regional setting}

Tibet and the bordering mountains formed as a consequence of the collision of the Indian and Eurasian continental plates initiated $\sim 50$ million years ago. Geologically, the region is a complex assemblage of rocks of different ages that are still actively being deformed by the continued northward movement of the Indian continental plate at $\sim 50 \mathrm{~mm} /$ year (DeMets et al. 1994). The average altitude across the HimalayanTibetan region is $\sim 5000 \mathrm{~m}$ a.s.l. (Fielding 1996). The region stretches $\sim 2000 \mathrm{~km}$ and $\sim 1500 \mathrm{~km}$ in an east-west and north-south direction, respectively (Fig. 1). This mountain mass comprises a series of approximately east-west trending ranges that include, from south to north, the Siwaliks, Lesser Himalaya, Greater Himalaya, Transhimalaya, Nyaingentanglha Shan, Tanggula Shan, Bayan Har Shan, Kunlun Shan, Altun Shan and Qilian Shan. We include the Pamir, Tian Shan and Altai Mountains in our study region because they broadly border the Tibetan-Himalayan region to the west (Fig. 1).

These mountain ranges are influenced by four major climatic systems: the mid-latitude westerlies, the south Asian monsoon, the Mongolian high-pressure system and the El Nino Southern Oscillation (ENSO). The relative importance of each varies throughout the region, with the eastern end and the southern slopes of the Himalaya being the wettest (Fig. 2). The southern slopes of the Himalaya and the high mountains of eastern Tibet receive snowfall mainly in the summer monsoon season, whereas northern and western Tibet, and ranges such as the Karakoram Mountains, Pamir, Tian Shan and Altai, receive heavy snowfalls during the winter with moisture supplied from the mid-latitude westerlies and the Mongolian high pressure system (e.g. Böhner 1996). This snow supports ice caps and valley glaciers throughout Tibet and the bordering mountains. As a consequence, the region presently has the largest concentration of glaciers outside the Polar Regions ( $126200 \mathrm{~km}^{2}$; Haeberli et al. 1989).

Major rivers, including the Indus, Ganges, TsangpoBhramaputra, Mekong, Yangtze and Huanghe, drain the region. They are essentially fed by glacial meltwater and monsoon precipitation; they have discharges and they produce sediment loads that are among the highest in the world. Furthermore, these rivers are essential for the agricultural, industrial and domestic needs of approximately three-quarters of the world's population. 

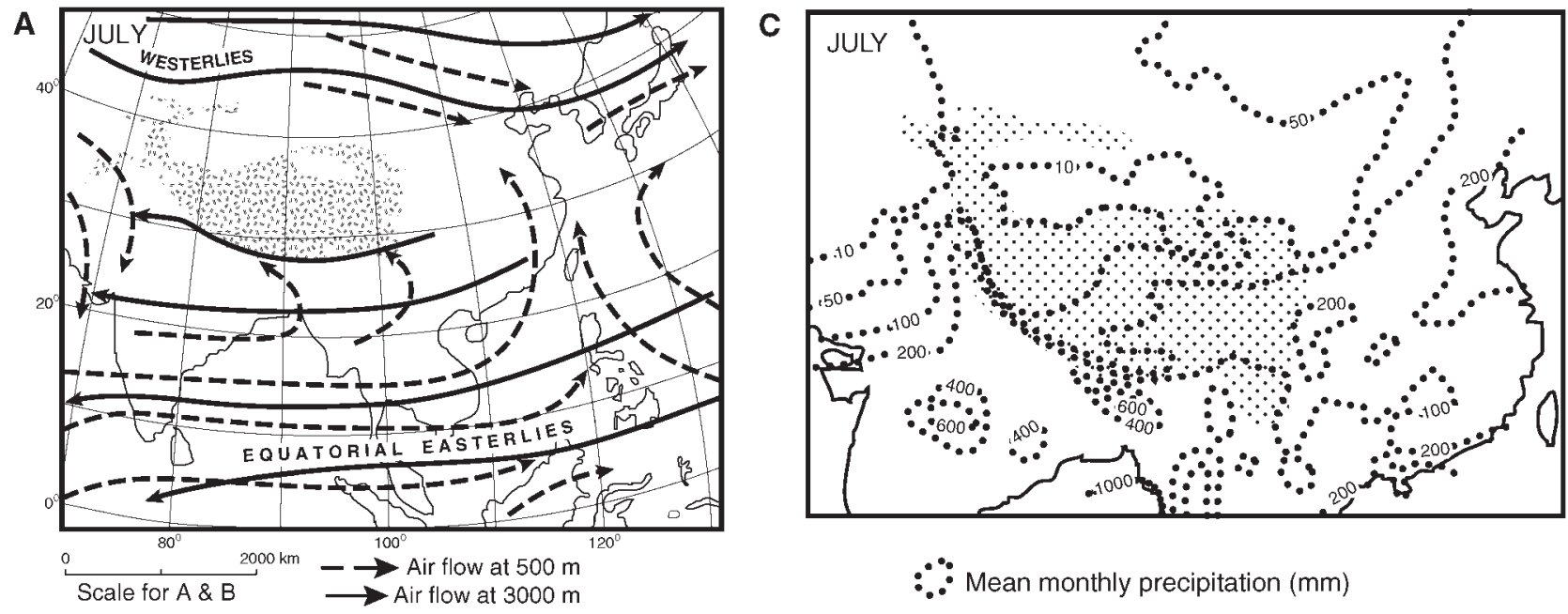

B
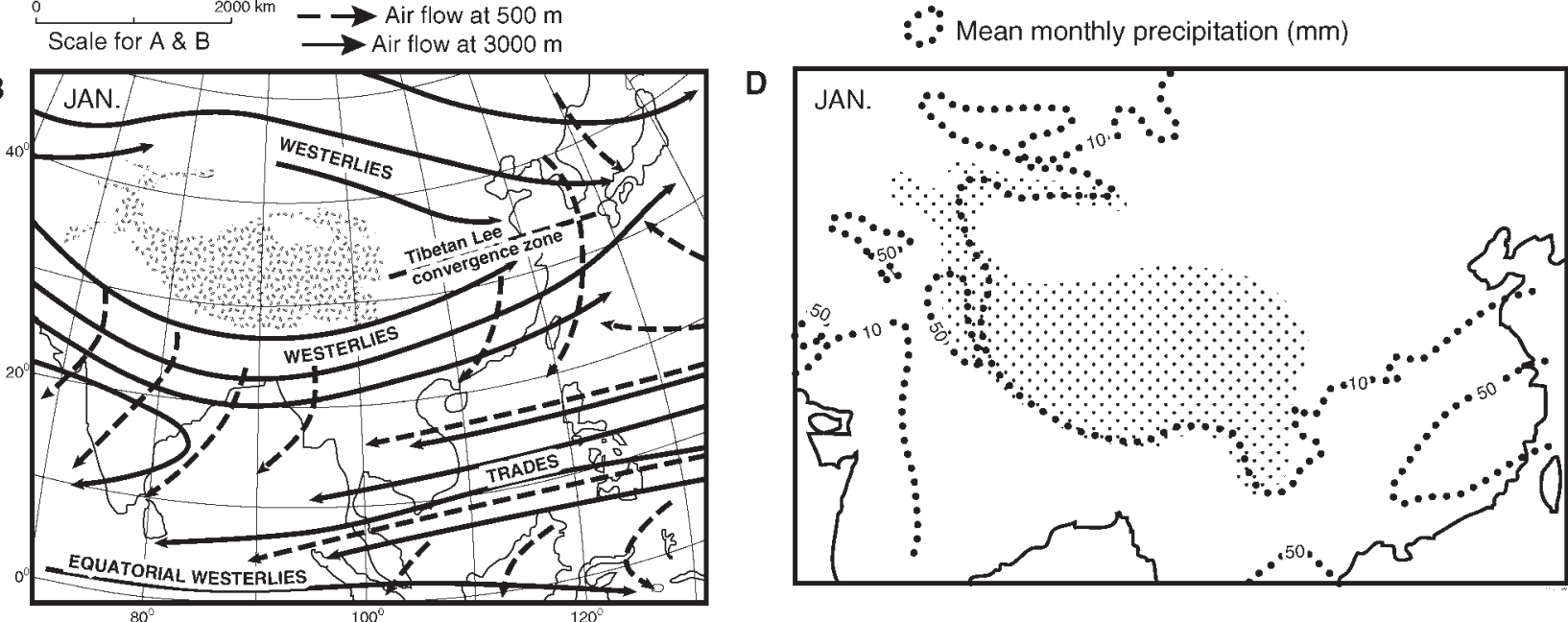

Fig. 2. Characteristic air circulation (A \& B) and precipitation (C \& D) over southern and central Asia. The Tibetan Plateau and bordering mountains above $5000 \mathrm{~m}$ a.s.l. are shown within the dotted areas. The solid lines in (A) and (B) indicate airflow at about $6000 \mathrm{~m}$ a.s.l. and $3000 \mathrm{~m}$ a.s.l., respectively, and the dashed lines airflow at about $600 \mathrm{~m}$ a.s.l. (C) and (D) show the strong N-E and E-W precipitation gradients (adapted from Owen et al. 1998 and Benn \& Owen 1998).

\section{Timing and extent of glaciation}

Relative glacial chronologies have been developed throughout the Himalaya and Tibet using morphostratigraphy aided by relative weathering studies (e.g. Burbank \& Kang 1991; Hövermann et al. 1993a,b; Hövermann \& Lehmkuhl 1994; Lehmkuhl 1995a,b, 1997, 1998b; Owen et al. 1997; Lehmkuhl et al. 2000, 2002) and soil development (e.g. Bäumler et al. 1997; Guggenberger et al. 1998; Zech et al. 2000). Reconstructing palaeoenvironmental change from glacial geologic evidence in Tibet and the bordering mountains has been difficult because of the lack of organic material for radiocarbon dating, and the problems of correctly identifying the origin of highly dissected landforms. Numerous radiocarbon dates are available for the wetter parts of the Himalayan-Tibetan region, but most are limited to Holocene proglacial deposits that poorly define the timing of glaciation
(Röthlisberger \& Geyh 1985; Lehmkuhl 1995a, 1997). Newly developing techniques that include optically stimulated luminescence (OSL) and cosmogenic surface exposure dating are now allowing glacial successions throughout Tibet and the bordering mountains to be dated and correlated (Lehmkuhl et al. 2000, 2002; Phillips et al. 2000; Richards et al. 2000a, b; Owen et al. 2001, 2002a, b, c, 2003a, b, c, 2005; Schäfer et al. 2002; Tsukamoto et al. 2002; Finkel et al. 2003; Zech et al. 2003; Spencer \& Owen 2004; fig. 3).

\section{Tibet}

Reconstruction of the extent of glaciation across the Tibetan Plateau has a long history (Klute 1930; Frenzel 1960; Kuhle 1985; Frenzel et al. 1992; Ono et al. 2004; Klinge \& Lehmkuhl 2004). More recently, Chinese workers have compiled synthesis maps to show the 
probable extent of glaciation across the Tibetan Plateau (Shi et al. 1986, 1993; Liu et al. 1988; Shi 1988; Li et al. 1991; Shi 1992). In a series of articles, Kuhle (1985, 1986, 1987, 1988a,b, 1990a, b, 1991, 1993, 1995) hypothesized that an extensive ice sheet covered essentially the whole of the Tibetan Plateau during glacial times. The existence of an extensive ice sheet has been one of the most contentious glacial issues concerning Tibet over the past few decades. Numerous publications, however, discuss the evidence against an extensive ice sheet (Derbyshire 1987; Zheng 1989; Pu 1991; Shi 1992; Hövermann et al. 1993a, b; Lehmkuhl 1995a, 1998b; Rutter 1995; Lehmkuhl et al. 1998; Zheng \& Rutter 1998; Zhou \& Li 1998; Schäfer et al. 2002; Owen et al. 2003c) and it is now generally accepted that a large ice sheet did not cover the Tibetan Plateau, not at least during the past few glacial cycles (see more detailed discussion below).

One of the main reasons for the differing opinions on the distribution and extent of Pleistocene glaciations on and around the Tibetan Plateau is the lack of general agreement on terminology and stratigraphic division of the different end moraine sequences and till deposits in the various mountain areas (Lehmkuhl 1997). Some relative chronologies exist for mountain glaciations, but the timing of glacier oscillations is poorly understood due to the lack of known numerical ages on moraines. Even a common relative stratigraphy based on ELA depressions, such as the one developed for the European Alps, is not available. An evaluation of recent glacial geologic studies suggests that Li et al. (1991) provide the best reconstruction of the extent of glaciation for the entire Tibetan Plateau. Their map shows limited glaciation in the interior of the Tibetan Plateau but expanded ice caps and valley glaciers on its margins during the last glacial cycle. They also provide a reconstruction of the former extent of a small ice sheet in northeast Tibet during the penultimate glacial cycle. The lack of numerically dated glacial landforms, however, makes it difficult to test whether the glacial limits that they map are not diachronous. The exact details of the extent of glaciation at particular times during the Quaternary are therefore still highly debated.

In the Chinese literature, the last glaciation is commonly divided into two main stages. These are thought to represent glaciations that occurred during marine oxygen isotope stages (MIS) 2 and 4 and are separated by an interstadial that lasted from about 55 to 32 ka (e.g. Liu et al. 1985; Li \& Pan 1989; Thompson et al. 1989, 1997; Zhang et al. 1991). Chinese workers such as Li \& Shi (1992) and Li \& Pan (1989) argue that the expanded ice caps and valley glaciers on the Tibetan Plateau during the last glacial began substantial retreat between 15 and $13 \mathrm{ka}$. Much of this work is summarized in Lehmkuhl (1995a), Owen et al. (1997) and Benn \& Owen (1998). The summary articles emphasize, however, that the timing of glaciation is poorly defined because of the limited number of numerical dates that were undertaken in these studies and state that great care should be taken in making regional generalizations about the timing and extent of glaciation.

During the past decade, however, OSL and cosmogenic surface exposure dating has been providing new insights into the ages of glacial landforms and the timing of glaciation. Studies using these techniques are showing that glaciation was restricted in extent during the last glacial cycle in regions such as central Tibet. In particular, Lehmkuhl et al. (2000, 2002) have shown that the morphology of the northern Nyainqêntanglha Shan and Mt. Jaggang, as well as the surroundings of Lakes Siling Co and Dagze Co, has demonstrated that the extent of ice during the late Quaternary was very limited. A luminescence date of $89 \pm 10 \mathrm{ka}$ on aeolian silt that overlies the oldest terminal moraines on the northern slope of the Nyainqêntanglha Shan helped define the timing of the penultimate glaciation (Lehmkuhl et al. 2002). In addition, Schäfer (2000) and Schäfer et al. (2002) presented cosmogenic surface exposure dates from the Tanggula Shan, dating moraines to between $123 \mathrm{ka}$ and $261 \mathrm{ka}$ that were only a few tens of kilometers beyond the present ice margins. These data suggest that there was no extensive plateau glaciation around $20 \mathrm{ka}$ and that there was no ice sheet over the whole of Tibet during the Late or Middle Pleistocene. Owen et al. (2005) confirmed the Schäfer et al. (2002) study by undertaking a more extensive examination of the Tanggula Shan and extending their work onto the eastern slopes of the Nyainqêntanglha Shan.

Studies on the glacial successions in the Anyemaqen and Nianbaoyeze mountains in NE Tibet using cosmogenic surface exposure dating methods suggest that glaciers in the more monsoon-influenced regions of Tibet advanced during times of increased insolation, such as MIS-3 and the early Holocene (Owen et al. 2003c). This suggests that increased moisture flux during these times created higher precipitation in the form of snow at high altitude, which in turn led to positive glacial mass balances and glacial advance. However, although precipitation would have been reduced during the insolation minima of MIS-2 (global Last Glacial Maximum: LGM), temperatures were low enough to lead to positive glacier mass balances, allowing glaciers to advance, albeit not as far as during MIS-3.

Lakes records (sediments and shorelines) in Tibet and the adjacent deserts support the view that higher moisture flux occurred during times of increased insolation. Summaries of fluctuations of late Quaternary lake levels in Tibet and the desert margins of central Asia are provided in Fang (1991), Gasse et al. (1991, 1996), Frenzel (1994), Pachur et al. (1995), Tarasov et al. (1996), Benn \& Owen (1998), Qin \& Yu (1998), Tarasov \& Harrison (1998) and Wünnemann et al. (1998). A discussion of the relationship between 
lake level changes, mountain glacier fluctuations and desert margins, and regional palaeoenvironmental changes in Central Asia is reviewed in Lehmkuhl \& Haselein (2000).

There is increasing evidence for limited glacier advances during MIS-2 (LGM) throughout the semiarid and monsoon-influenced regions of Tibet (Schäfer et al. 2002; Owen et al. 2003a, b, c, 2005). Schäfer et al. (2002), for example, produced cosmogenic surface exposure ages on erratics from the eastern margin of the Tibetan Plateau (close to the city of Litang, $99^{\circ} 33^{\prime} \mathrm{E}, 30^{\circ} 15^{\prime} \mathrm{E}$ ) indicating that valley glaciation was only $10 \mathrm{~km}$ away from the present glacier snout. These were dated between $14 \mathrm{ka}$ and $30 \mathrm{ka}$ and suggest that the main glacial advance was at $17000 \pm 1000 \mathrm{yr}$ BP. Similarly, in the Qilian Shan and Li Ji Mountains in NE Tibet, cosmogenic surface exposure and OSL ages support limited glacial advances during the LGM ( $<10 \mathrm{~km}$ long; Owen et al. 2003a, b). Likewise, on the Karola Pass in southern Tibet north of the Transhimalya, Owen et al. (2005) provide cosmogenic surface exposure ages on moraines that demonstrate a MIS-2 glacial advance $<10 \mathrm{~km}$ in extent.

There are only a few published studies on the Lateglacial and Holocene fluctuations of mountain glaciers on the Tibetan Plateau and the surrounding areas $(\mathrm{Pu}$ 1991; Lehmkuhl 1997; Owen et al. 2003a, b, c, 2005). Glacier advances have been dated to about $15 \mathrm{ka}$ in West Kunlun, in the Tian Shan and in the mountain areas surrounding the Qaidam Basin (Kang 1992; Shi 1992; Guo et al. 1995; Owen et al. 2003a). Several Chinese authors (e.g. Wang \& Fan 1987) argue for Holocene glacier advances, but most do not differentiate between Lateglacial end moraines or ice marginal limits and the LGM (MIS-2) terminal moraines. Chronology is mainly based on radiocarbon dating of organic matter that overlies terminal moraines. These dates are minimum ages and consequently only a few Pleistocene and Holocene glacial advances have been dated with a sufficient degree of confidence. Beug (1987), Wang \& Fan (1987) and Lehmkuhl (1995a) suggest that Early Holocene glaciers had approximately the same size as modern glaciers. However, recent cosmogenic surface exposure dating of moraines in the Anyemaqen, on the Karola Pass and Gonga Shan suggest that glaciers advanced several kilometers beyond their present positions during the Early Holocene with an ELA depression of approximately $100 \mathrm{~m}$ (Owen et al. 2003c, 2005). The Little Ice Age and Neoglacial moraines are defined by dates on wood and branches incorporated in moraines in southern Tibet (Arza glacier; Wang \& Fan 1987) and, for example, in the Qilian Shan ( $\mathrm{Pu}$ 1991). Pollen records show a cooler and moister period during the Late Holocene (e.g. Sun \& Chen 1991; Schlütz 1999). Historical records suggest that brief cold and wet intervals occurred periodically throughout the Late Holocene. These have been reported from the
Taklimagan desert (in the Tarim Basin; Fig. 1) at about 2000 years BP and during the Little Ice Age for example (Yang 1991; Yang et al. 2002).

The nature of glacial fluctuations since the Little Ice Age (17th to 19th centuries) is discussed in Su \& Shi (2002). They show that the mean temperature of monsoonal temperate glaciers in China has increased by $0.8^{\circ} \mathrm{C}$ since the Little Ice Age and has resulted in a decrease that amounts to an equivalent of $30 \%$ of the modern glacier area, a loss of some $4000 \mathrm{~km}^{2}$ of glaciated area. They predict that by the year 2100 the temperature in the monsoonal temperate glaciers of China will rise by $2.1^{\circ} \mathrm{C}$ and that the glacier area will decrease by $75 \%\left(\sim 9900 \mathrm{~km}^{2}\right.$ loss of glaciated area). Furthermore, they predict that precipitation will decrease in the coming decades and that glacier retreat will accelerate, but they argue it is unlikely to exceed a loss of $80 \%$ of the total glaciated area. General circulation models for global warming, however, suggest that monsoon precipitation will increase in the coming years, which may lead to increased snowfall and positive glacier mass balances. Therefore, there is considerable uncertainty as to the future of Tibetan glaciers. However, there is little doubt that glaciers have been retreating and that glacier ice has been warming throughout the last century. Such conditions clearly pose a serious threat to the water resources and environment throughout Central Asia.

\section{Himalaya and Transhimalaya}

A comprehensive review of the Quaternary glacial history of the Himalaya was presented in Owen et al. (1998), and Owen et al. (2002a) evaluated studies of the extent of glaciation throughout the Himalaya during the global LGM $(\sim 18-24 \mathrm{ka})$ as part of the EPILOG (Environmental Processes of the Ice Age: Land, Ocean, Glaciers) program of IGBP/PAGES program IMAGES (International Marines Studies of Global Change). Further descriptions of the Quaternary glacial history of each Himalayan region are provided in Ehlers \& Gibbard (2004). The new data highlighted in these publications show that the local last glacial maximum for most of the Himalaya occurred during the early part of the last glacial cycle. In most areas, this probably occurred during MIS-3. In contrast, during the global LGM, glaciation was generally restricted throughout most of the Himalaya and Transhimalaya, with glaciers advancing less than $10 \mathrm{~km}$ from contemporary ice margins. Furthermore, recent OSL and comsogenic radionuclide surface exposure dating by Richards et al. (2000b) and Finkel et al. (2003) in the Khumbu Himal supports the view that glacial advances were restricted $(<5 \mathrm{~km})$ during the global LGM (MIS-2), with the local last glacial maximum occurring in the earlier part of the last glacial cycle. Correlating numerical dating studies, Finkel et al. (2003) suggest that glaciations can 

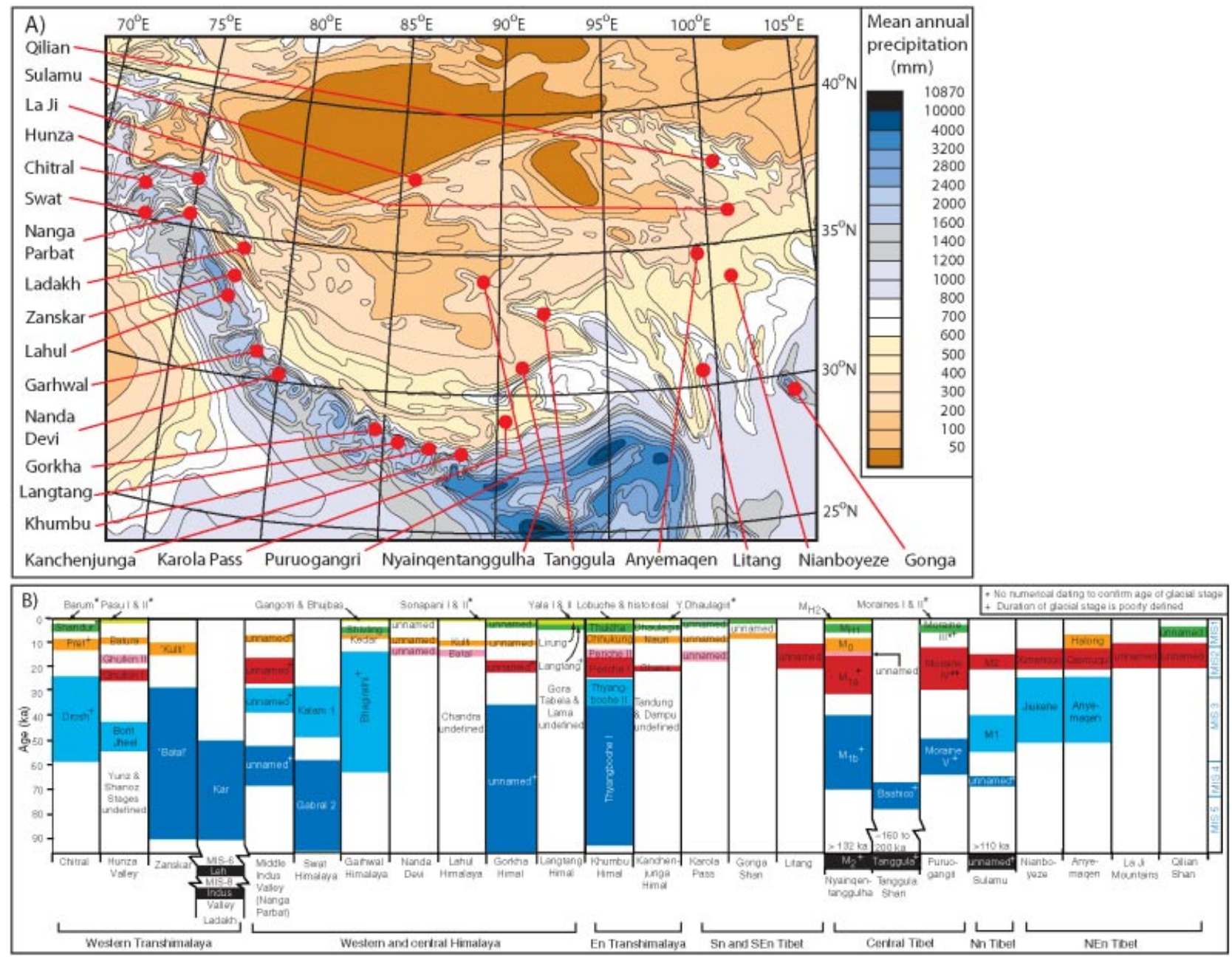

Fig. 3. The contemporary mean annual (A) precipitation across Tibet and the bordering regions showing (B) the locations and glacial chronologies that have reliable numerical dates in the Himalaya and Tibet (adapted from Owen et al. 2005). The color bars in (B) represent the likely duration of each glacial advance and the name of each glacial stage has been inserted into the box. An asterisk and cross after each name indicate that no numerical dating has been undertaken to confirm an age and the duration of the glacial is poorly defined, respectively. A tentative correlation is suggested by applying similar colors to the bars of the glacial stages that are likely synchronous. (MIS $=$ marine oxygen isotope stage).

be broadly correlated along the Himalaya. This is summarized in Fig. 3.

The pattern of glaciation, however, appears to be different in the Hindu Kush at the far western end of the Himalayan-Tibetan orogen. Here, Owen et al. (2002c) showed that extensive valley glaciers extended to an altitude of $\sim 1670 \mathrm{~m}$ a.s.l. during the LGM. Despite this study, most of the data help confirm the view of Benn \& Owen (1998) that glaciation through the Himalayan-Tibet region was asynchronous with the Northern Hemisphere ice sheets, with the maximum glacial advances occurring during MIS-3 or MIS-5a to $5 \mathrm{~d}$ (Owen et al. 2005). This asynchroneity is attributed to increased precipitation as snow at high altitudes due to a strengthened monsoon that penetrated further north into the Himalaya during times of increased insolation. In contrast, during times of lower insolation, particularly the global LGM (MIS-2), the influence of the monsoon was reduced, which in turn resulted in lower snowfall and snow accumulation and less extensive glaciation.

It has long been recognized that glaciers throughout the Himalaya and Transhimalayan regions have been retreating throughout the last century (Mayewski \& Jeschke 1979; Mayewski et al. 1980), but the extent of retreat has not been adequately quantified. As discussed earlier with regard to Tibetan glaciers, it is difficult to assess the likely future trends due to global warming because of the complex feedbacks due to the predicted increase in monsoon precipitation and subsequent increased snowfall leading to possible positive glacier mass balances. Nevertheless, presently retreating glaciers pose serious threats to water resources on the Indian subcontinent as well as hazards such as those from 
glacial lake outburst floods (GLOFs) that are common as glaciers retreat (Richardson \& Reynolds 2000).

\section{Tian Shan and Altai Mountains}

There are differing opinions concerning the extent of Late Pleistocene ice in the mountains north of the desert regions of Central Asia. Grosswald et al. (1994) and Grosswald \& Kuhle (1994) present the view that an extensive ice sheet existed in these regions during the last glacial cycle. They argued that, in the Tian Shan, Late Pleistocene glaciers extended to the foothills, and mountain glaciers south of Lake Baikal terminated in the lake. They estimated LGM ELA depressions to be between 1150 and $1400 \mathrm{~m}$ for the Tian Shan, and about $1500 \mathrm{~m}$ for the mountains south of Lake Baikal. In contrast, Zech et al. (1996) and Heuberger \& Sgibnev (1998) show clear evidence that glaciers were restricted to the Tian Shan mountain range and did not reach the foothills and had significantly lower ELA depressions than suggested by Grosswald et al. (1994) and Grosswald \& Kuhle (1994).

The extent of Pleistocene glaciation in the Russian Altai is debated, but most researchers argue that valley glaciers reached Lake Teleski at $430 \mathrm{~m}$ a.s.l. (e.g. Baryshnikov 1992; Budvylovski 1993). The extent of ice was much greater in the western part of the Russian Altai than in the eastern region. In the eastern region, valley glaciers stretched down to the Kuray and Chuya Basins damming the main rivers and forming icedammed lakes, which produced the largest mega-floods (GLOFs) in the world (Baker et al. 1993; Rudoi 2002). In the eastern part of the Russian Altai and the Mongolian Altai there is evidence of two major Pleistocene glaciations of similar extent (Lehmkuhl 1998a; Klinge 2001; Klinge et al. 2003; Lehmkuhl et al. 2004). The limited extent of present and Pleistocene glaciers in the western part of the Russian Altai and in the Mongolian Altai is the result of reduced precipitation from west to east, which causes a rise of present and Pleistocene ELAs towards the east. There is an essential lack of numerical dating of glacial sediments in this particular region. Nevertheless, according to the present knowledge, most Late Pleistocene glacier advances in Mongolia and in the Russian Altai took place during MIS 2 and 4 (Grunert et al. 2000; Lehmkuhl et al. 2004).

\section{Quantifying climate change from glacial geologic data}

The most common method for reconstructing climate from glacial data is the use of glacier equilibrium lines. Benn \& Lehmkuhl (2000) discuss the mass balance and glacier characteristics of glaciers in the high mountains of Asia and review the methods used to reconstruct former ELAs. They emphasize that methods of ELA reconstruction employed in low-relief environments are not always applicable in high mountains. Benn \& Lehmkuhl (2000) argue that some of the methods of ELA estimation (e.g. terminus-to-headwall ratio: THAR) do not give true ELAs, and suggest glacial elevation indices (GEIs) as a more appropriate term, especially in the steep relief of the Himalaya and the Karakoram. Nonetheless, GEIs/ELAs are useful for reconstructing gradients across regions and for regional comparisons. Local and regional variations in ELAs are common in the mountains of Northern India, as shown by the work of Burbank \& Fort (1985), Holmes \& Street-Perrott (1989) and Sharma \& Owen (1996). Nevertheless, these methods show that ELAs during Pleistocene glaciations dropped by between 300 to $500 \mathrm{~m}$ in the drier parts, and 600 to more than $1000 \mathrm{~m}$ in the wetter parts of the Tibetan Plateau and Himalaya. Figure 4 illustrates examples of present and Pleistocene glaciers and ELAs and can be used to help illustrate and semi-quantify the nature of glaciation in the high mountains of central Asia.

Profile $A-A^{\prime}$ in Fig. 4 shows the distribution of present and Pleistocene ice from the Russian Altai in the west towards the Mongolian Altai in the east. The present ELAs in the Russian Altai and Mongolian Altai are between 2600 and $3100 \mathrm{~m}$ a.s.l. and between 3100 and $3600 \mathrm{~m}$ a.s.1., respectively (Bussemer 2001; Klinge 2001). The Late Pleistocene ELA is calculated to be $\sim 2000 \mathrm{~m}$ a.s.l. in the eastern mountain ranges and $>2800 \mathrm{~m}$ a.s.l. in the western parts of the Russian Altai. The ELA depression was $>1000 \mathrm{~m}$ in the wettest parts of the western Russian Altai (today's annual precipitation: $>1000 \mathrm{~mm} / \mathrm{a}$ ) and between $800 \mathrm{~m}$ and $500 \mathrm{~m}$ in the eastern part of the Russian Altai and in the Mongolian Altai, respectively (Lehmkuhl et al. 2004). This regional gradient of the ELAs was steeper during glacial times. Further to the east, in the Khangay, the ELA depression is again $>1000 \mathrm{~m}$ (see below, profile $\left.\mathrm{C}-\mathrm{C}^{\prime}\right)$. This may be the consequence of a strong monsoonal influence, which is also evident further east in the mountains of Northern China as the Qinling Shan or Wutai Shan (Lehmkuhl \& Rost 1993; Rost 1998, 2000).

Profile B $-\mathrm{B}^{\prime}$ in Fig. 4 shows the increase in elevation of the ELA from the eastern margin towards the interior of the Tibetan Plateau for the Late Pleistocene (Lehmkuhl 1995a, 1998b). The Late Pleistocene ELA depression varies from between $800 \mathrm{~m}$ and $1000 \mathrm{~m}$ in the eastern part to $500 \mathrm{~m}$ in the western part of Tibet. There is a comparable increase of the modern and Late Pleistocene ELAs towards the plateau on the northern and northeastern flank; for example, from $3300 \mathrm{~m}$ a.s.l. in the Qinling Shan $\left(34^{\circ} 15^{\prime} \mathrm{N}, 109^{\circ} 10^{\prime} \mathrm{E}\right)$ to $4150 \mathrm{~m}$ a.s.l. in the $\mathrm{La}$ Ji Shan $\left(36^{\circ} 55^{\prime} \mathrm{N}, 101^{\circ} \mathrm{E}\right)$ (Lehmkuhl \& Rost 1993; Rost 2000). This general increase in ELA corresponds with the decrease in precipitation from east to west, which was more pronounced during glacial times (cf. Lehmkuhl 1995a). 


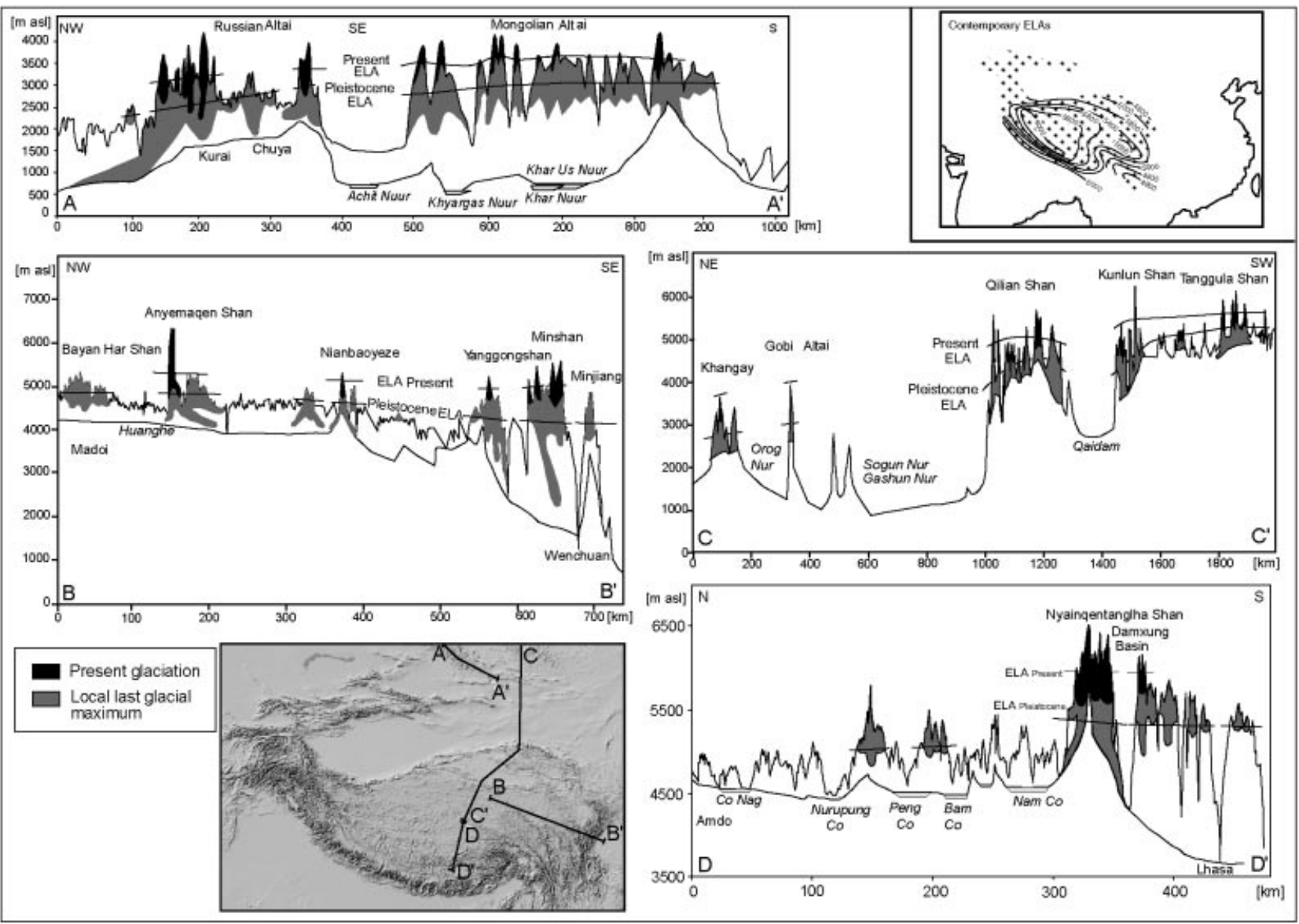

Fig. 4. Map with selected cross-sections of Central and High Asia, including the distribution of present and local last glacial maximum ice and the equilibrium line altitudes (ELAs). Cross-section A $-\mathrm{A}^{\prime}$ shows the distribution of present and local last glacial maximum ice and the ELAs from the Russian Altai to the Mongolian Altai (according to Klinge 2001 and Lehmkuhl 1999, 2002). Cross-section B - B' shows the distribution of present and local last glacial maximum ice and the ELAs from the Khangay and Gobi Altai to the Tibetan Plateau (according to Lehmkuhl 1995, 1997b). Cross-section C $-\mathrm{C}^{\prime}$ shows the distribution of present and local last glacial maximum ice and the ELAs from the eastern fringe of the Tibetan Plateau (according to Lehmkuhl 1995, 1998b). Cross-section D - D shows the distribution of present and local last glacial maximum ice and the ELAs from southern Tibet (according to Lehmkuhl et al. 2000, 2002). The inset map in the top right corner shows the variation in contemporary regional snowlines across Tibet and the bordering mountains (adapted from Benn \& Owen 1998).

In addition, fossil involutions (cryoturbation) and icewedge casts provide evidence for LGM permafrost in the Basin of Zoige (3400 to $3500 \mathrm{~m}$ a.s.l.) and on the southern shores of Qinghai Lake (Porter et al. 2001). Past temperatures can be estimated from these periglacial features and the existence of sand wedges indicates higher aridity - thus supporting the possibility that the ELA depression during the Late Pleistocene was between 600 and $800 \mathrm{~m}$ (Lehmkuhl 1998b).

The extent of late Quaternary glaciation from the mountains of Mongolia (Khangay and Gobi Altai) towards the northern, central and southern parts of the Tibetan Plateau is shown in Fig. 4. Presently, there are no glaciers in the central part of the Khangay and Gobi Altai (Profile $\mathrm{C}-\mathrm{C}^{\prime}$ in Fig. 4). However, Lehmkuhl \& Lang (2001) calculated the Pleistocene ELA to be between 2700 and $2800 \mathrm{~m}$ a.s.l. in the Khangay.
Lehmkuhl (1998a) suggested that Quaternary glaciers were present in the Gobi Altai during glacial times. This suggests that the ELA depression in the Gobi Altai was $\sim 1000 \mathrm{~m}$.

On the northern slopes of the Qilian Shan in northeast Tibet, the modern ELAs are between 4600 and $5000 \mathrm{~m}$ a.s.l. and the Pleistocene ELA is $\sim 3800 \mathrm{~m}$ a.s.l. (an ELA depression of $\sim 1000 \mathrm{~m}$; Lehmkuhl \& Rost 1993; Hövermann et al. 1998). The modern ELA is 200 to $300 \mathrm{~m}$ lower in the outermost ranges of the Qilian Shan than in the innermost ranges (cf. Lehmkuhl 1992, 1995b, 1998b; Shi 1992). This pattern is also seen south of the Qaidam basin, from the Kunlun Shan in the north towards the Tanggula Shan in the south-central part of the Tibetan Plateau (profile $\mathrm{C}-\mathrm{C}^{\prime}$ in Fig. 4). There is a sharp increase in elevation of the ELA from $4550 \mathrm{~m}$ a.s.l. in the innermost ranges of the Kunlun 
Shan on the northern slope towards the Plateau to $4950 \mathrm{~m}$ a.s.l. on the southern slope. This is the only range that is presently glaciated. It has an ELA of $\sim 5300 \mathrm{~m}$ a.s.l. and a Pleistocene ELA depression of $\sim 600 \mathrm{~m}$. At the marginal (outermost) northern range, Kuhle (1987) argues that the ELA depression during the Late Pleistocene was $\sim 1000 \mathrm{~m}$ a.s.l. However, on the southern slope of the main range of the Kunlun Shan system, which is $70 \mathrm{~km}$ wide, glaciers advanced only a few kilometres from the Kunlun Pass to the interior of the Plateau to the south. There is no evidence to support Kuhle's (e.g. 1993) hypothesis that glaciers transported boulders $400 \mathrm{~km}$ north from the central Tanggula Shan (cf. Lehmkuhl 1995a, 1998b; Lehmkuhl \& Hövermann 1996). In the Tanggula Shan, the modern ELAs are $~ 5700-5800 \mathrm{~m}$ a.s.l. and the Late Pleistocene ELA depression is between 500 and $600 \mathrm{~m}$ (Lehmkuhl 1998b). There is little difference between ELAs on the northern and southern sides of the Tanggula Shan. The general increase of modern and Late Pleistocene ELAs towards the plateau corresponds with the decrease in precipitation from north to south, which was more pronounced at the eastern margin during the ice age (cf. Lehmkuhl 1995a).

Profile D - D (Fig. 4) shows that the present ELA in Southern Tibet is between 5800 and $6000 \mathrm{~m}$ a.s.1., with a Pleistocene ELA depression of 300 to $500 \mathrm{~m}$ in the drier parts of the Plateau, and 600 to $800 \mathrm{~m}$ in the wetter southern and southwestern mountain slopes of the Nyainqêntanglha Shan. Luminescence dates on aeolian silt that overlies the oldest terminal moraines on the northern slope of the Nyainqêntanglha Shan indicate an older glacier advance of the penultimate glaciation $(89 \pm 10 \mathrm{ka}$; Lehmkuhl et al. 2002). However, the geomorphology of the areas north of the Nyainqêntanglha Shan shows clear evidence that the extent of ice during the Late Pleistocene was limited (Lehmkuhl et al. 2000, 2002). In addition, the cosmogenic surface exposure ages presented by Schäfer (2000), Schäfer et al. (2002) and Owen et al. (2005) in the Tanggula Shan provide evidence for a slightly larger extent of ice during the penultimate glaciation.

\section{Effects of surface uplift on glaciation}

Controversy exists over the timing and rates of uplift throughout Tibet and the bordering mountains. The extension exhibited by normal and reverse faulting along Tibet's margins, volcanic activity in northeastern Tibet and palaeobotanical evidence in southern Tibet, however, suggests that much of Tibet probably reached its present elevation by $\sim 13-14 \mathrm{Ma}$ (Colman \& Hodges 1995; Edwards \& Harrison 1997; Blisniuk et al. 2001; Spicer et al. 2003). The mountain ranges that surround the Tibetan Plateau are generally much younger than $13 \mathrm{Ma}$ and surface uplift rates are estimated to be a few $\mathrm{mm} /$ year (e.g. Zeitler et al. 2001). These uplift rates are usually defined using exhumation rates determined by fission track and mineral cooling ages, and incision rates determined from dating strath terraces and calculating contemporary sediment fluxes and volumes of deposited sediments (Collins 1998; Clift et al. 2001). Since the mountains produce positive relief, it is generally considered that the exhumation and incision rates must be less than or equal to the surface uplift rates. It is likely that current denudation is keeping pace with uplift and that the net gain in elevation is small. It is therefore highly unlikely that maximum uplift exceeds $10 \mathrm{~mm} /$ year and surface uplift is most likely in the order of $\sim 1 \mathrm{~mm} /$ year in the actively growing mountain ranges.

Most of the late Quaternary glacial geologic studies in Tibet and the bordering mountains are limited to the last 100000 years. A range of surface uplift rates between 1 and $10 \mathrm{~mm} /$ year suggests that the mountains have not uplifted $>100 \mathrm{~m}$ since $\sim 100 \mathrm{ka}$. In the most rapidly rising regions, such as Nanga Parbat, uplift could be in the order of several hundred metres to as much as a kilometre. In most regions, however, uplift is not considered to have greatly influenced the style of late Quaternary glaciation. The Ladakh Range of northern India may be an exception. Here, glaciation may have become dramatically more restricted over the past few hundred thousand years. Taylor \& Mitchell (2000) and Bovard (2001) suggest that the Greater Himalaya and Pir Panjal to the south may have uplifted enough to restrict the northward penetration of the south Asian summer monsoon, reducing precipitation and glacial cover.

\section{Conclusions}

An understanding of the nature of late Quaternary glaciation in Tibet and the bordering mountains is still in its infancy. However, the application of modern geomorphic and sedimentological techniques, and the development of new dating techniques, such as cosmogenic surface exposure and OSL dating, have opened up the possibility for regional and temporal correlations across this vast region. Although the extent of former glaciers is relatively well known, in most regions it is still not known when glaciers advanced to particular positions. Nevertheless, at this stage we are able to conclude the following:

- In most regions of Tibet and much of the Himalaya, glaciation was most extensive earlier in the last glacial cycle, possibly MIS-3 or MIS-5a to 5d. Furthermore, glaciation was generally most extensive prior to the last glacial cycle. It is possible, however, that the behaviour of glaciers influenced by the different climatic systems was different at different times, and more detailed geomorphic and geochronological studies are needed to fully explore regional variations. 
- There is a strong topographic control on glaciation, particularly in regions that have rainshadow effects. This is most evident from the strong regional variability in present and past ELAs.

- Glaciation was more extensive in monsoon-influenced regions, and was strongly controlled by changes in insolation that control the geographic extent of the monsoon and consequently precipitation distribution. This strongly influences glacier mass balances, allowing glaciers to advance during times of increased precipitation in high altitude regions, and these are associated with insolation maxima during glacial times.

- Tectonic uplift has had little effect on glaciation during the last glacial cycle, but may have been important in controlling differences in glacial styles and extent over many hundreds of thousands of years.

- Drainage development, including lake level changes, has been strongly controlled by climatic oscillations, particularly on millennial time scales. However, centennial and decadal fluctuations are also discernible.

- Changes in glacial ice volume after the global LGM were relatively small in the Tibet-Himalayan region compared to the Northern Hemisphere ice sheets. It is therefore unlikely that meltwater draining from Tibet and the bordering mountains during the Lateglacial and early Holocene would have been sufficient to affect oceanic circulation upon flowing into the adjacent oceans. However, changes in surface albedo may have influenced the dynamics of monsoonal systems and had implications for global climate change.

- Despite the relatively small volume of glacial ice that existed in this region during glacial times, Tibet and the bordering mountains presently have the greatest concentration of glaciers outside the Polar Regions. Since the Little Ice Age, and particularly during this century, glaciers have been progressively retreating. This pattern is likely to continue throughout this century, exacerbated by humaninduced global warming.

Acknowledgements. - This is a contribution to IGCP 415 (Glaciation and Reorganization of Asia's Network of Drainage) co-led by Jim Teller, and it is part of a collection of IGCP 415 papers to be published in Boreas and edited by Jim Teller and Jan A. Piotrowski. We thank especially the members of Working Groups 2 and 7. Thanks to UNESCO for supporting the IGCP project. Particular thanks are extended to Douglas Benn and Nat Rutter, who reviewed this paper, and to Nicole Davis for providing useful comments on the manuscript. The editor of Boreas, Jan A. Piotrowski, is thanked for his expert help in the final shaping of the paper.

\section{References}

Baker, V. R., Benito, G. \& Rudoi, A. N. 1993: Palaeohydrology of late Pleistocene superflooding, Altay Mountains, Siberia. Science $259,348-350$.
Barnard, P. \& Owen, L. A. 2000: A selected bibliography for Late Quaternary glaciation in Tibet and the bordering mountains. Quaternary International 65/66, 193-212.

Baryshnikov, G. J. 1992: Die Entwicklung des Reliefs der Übergangszonen von Bergländern im Kanäozoikum. 181 pp. University of Tomsk Press, Tomsk (in Russian).

Bäumler, R., Madhikermi, D. P. \& Zech, W. 1997: Fine silt and clay mineralogical changes of a soil chronosequence in the Langtang Valley (Central Nepal). Journal of Plant Nutrition and Soil Science 160, 353-363.

Benn, D. I. \& Lehmkuhl, F. 2000: Mass balance and equilibriumline altitudes of glaciers in high mountain environments. Quaternary International 65/66, 15-29.

Benn, D. I. \& Owen, L. A. 1998: The role of the Indian summer monsoon and the mid-latitude westerlies in Himalayan glaciation; review and speculative discussion. Journal of the Geological Society of London 155, 353-364.

Benn, D. I. \& Owen, L. A. 2002: Himalayan glacial sedimentary environments: a framework for reconstructing and dating former glacial extents in high mountain regions. Quaternary International 97/98, 3-25.

Benn, D. I., Owen, L. A., Osmaston, H. A., Seltzer, G. O., Porter, S. C. \& Mark, B. 2005: Reconstruction of equilibrium-line altitudes for tropical and sub-tropical glaciers. Quaternary International (in press).

Beug, H.-J. 1987: Palynological studies on a peat layer in Kakitu Mountain, Northeastern Qinghai-Xizang Plateau. In Hövermann, J. \& Wang, W. (eds.): Reports on the Qinghai-Xizang (Tibet) Plateau, 496-501. Science Press, Beijing.

Blisniuk, P. M., Hacker, B. R., Glodny, J., Ratschbacher, L., Bi, S., Wu, Z., McWilliams, M. O. \& Calvert, A. 2001: Normal faulting in central Tibet since at least $13.5 \mathrm{Myr}$ ago. Nature 412, 628-632.

Böhner, J. 1996: Säkulare Klimaschwankungen und rezente Klimatrends Zentral- und Hochasiens. Göttinger Geographische Abhandlungen 101, $166 \mathrm{pp}$.

Bovard, K. 2001: Quaternary Paleoenvironmental Change and Landscape Evolution in the Upper Indus Valley Ladakh. M.S. thesis, University of California, $187 \mathrm{pp}$.

Broecker, W. S., Kennett, J. P., Flower, B. P., Teller, J. T., Trumbore, S., Bonani, G. \& Wolfli, W. 1989: Routing of meltwater from the Laurentide Ice Sheet during the Younger Dryas cold episode. Nature 341, 318-320.

Budvylovski, V. V. 1993: Palaeogeography of the Last Glaciation and Holocene in the Altai. 251 pp. University of Tomsk Press, Tomsk (in Russian).

Burbank, D. W. \& Fort, M. B. 1985: Bedrock control on glacial limits; examples from the Ladakh and Lanshan Ranges, northwestern Himalaya, Indian. Journal of Glaciology 31, 143-149.

Burbank, D. W. \& Kang, J. C. 1991: Relative dating of Quaternary moraines, Rongbuk Valley, Mount Everest, Tibet: implications for an ice sheet on the Tibetan Plateau. Quaternary Research 36, $1-18$.

Bussemer, S. 2001: Jungquartäre Vergletscherung im Bergaltai und in angrenzenden Gebirgen - Analyse des Forschungsstandes. Mitteilungen der Geographischen Gesellschaft in München 85, 45-64.

Clift, P. D., Shimizu, N., Layne, G. D., Blusztajn, J. S., Gaedicke, C., Schuter, H.-U., Clark, M. K. \& Amjad, S. 2001: Development of the Indus Fan and its significance for the erosional history of the Western Himalaya and Karakoram. Geological Society of America Bulletin 113, 1039-1051.

Collins, D. N. 1998: Suspended sediment flux in meltwaters draining from the Batura glacier as an indicator of the rate of glacial erosion in the Karakoram Mountains. In Owen, L. A. (ed.): Mountain Glaciation, 1-10. John Wiley and Sons Ltd., Chichester.

Colman, M. \& Hodges, K. 1995: Evidence for Tibetan plateau uplift before $14 \mathrm{Myr}$ ago from a new minimum age for east-west extension. Nature $374,49-52$. 
DeMets, C., Gordon, R. G., Argus, D. F. \& Stein, S. 1994: Effects of recent revisions to the geomagnetic reversal time scale on estimates of current plate motion. Geophysical Research Letters 21, 2191-2194.

Derbyshire, E. 1987: A history of the glacial stratigraphy in China. Quaternary Science Reviews 6, 301-314.

Edwards, M. A. \& Harrison, T. M. 1997: When did the roof collapse? Late Miocene north-south extension in the high Himalaya revealed by $\mathrm{Th}-\mathrm{Pb}$ monazite dating of the Khula Kangri Granite. Geology 25, 543-546.

Ehlers, J. \& Gibbard, P. (eds.) 2004: Quaternary glaciations - extent and chronologies. Part III: South America, Asia, Africa, Australia, Antarctica. Developments in Quaternary Science 2, $380 \mathrm{pp}$.

Fang, J. 1991: Lake evolution during the past 30,000 years in China and its implications for environmental change. Quaternary Research 36, 37-60.

Fielding, E. J. 1996: Tibet uplift and erosion. Tectonophysics 260, $55-84$.

Finkel, R. C., Owen, L. A., Barnard, P. L. \& Caffee, M. W. 2003: Beryllium-10 dating of Mount Everest moraines indicates a strong monsoonal influence and glacial synchroneity throughout the Himalaya. Geology 31, 561-564.

Frenzel, B. 1960: Die Vegetations- und Landschaftszonen Nordeurasiens während der letzten Eiszeit und während der Postglazialen Warmezeit. Abhandlungen mathematisch-naturwissenschaftlichen Klasse der Akademie der Wissenschaften und der Literatur 13, 937-1099.

Frenzel, B. 1994: Zur Paläoklimatologie der letzten Eiszeit auf dem tibetischen Plateau. Göttinger Geographische Abhandlungen 95, 115-142.

Frenzel, B., Pecsi, M. \& Velichko, A. A. (eds.) 1992: Atlas of Paleoclimates and Paleoenvironments of the Northern Hemisphere: Late Pleistocene-Holocene. 153 pp. Gustav Fischer Verlag, Stuttgart.

Gasse, F., Arnold, M., Fontes, J. Ch., Fort, M., Gilbert, E., Huc, A., Li, B., Li, Y., Liu, Q., Mélières, F., Van Campo, E., Wang, F. \& Zhang, Q. 1991: A 13,000-year climate record from western Tibet. Nature 353, 742-745.

Gasse, F., Fontes, J. C., Van Campo, E. \& Wei, K. 1996: Holocene environmental changes in Bangong Co Basin (Western Tibet Part 4, Discussion and Conclusions). Palaeogeography, Palaeoclimatology, Palaeoecology 120, 79-92.

Grosswald, M. G. \& Kuhle, M. 1994: Impact of glaciations on Lake Baikal. In Horie, S. (ed.): International Project on Paleolimology and Late Cainozoic Climate, 8, 48-60. Universitätsverlag Wagner, Innsbruck.

Grosswald, M. G., Kuhle, M. \& Fastook, J. L. 1994: Würm Glaciation of Lake Issyk-Kul Area, Tian Shan Mts: a case study in glacial history of Central Asia. GeoJournal 33, 273-310.

Guggenberger, G., Bäumler, R. \& Zech, W. 1998: Weathering of soils developed in eolian material overlying glacial deposits in Eastern Nepal. Soil Science 163, 325-337.

Guo, H, Chen, Y. \& Li, J. 1995: A preliminary study on glacial sequences, loess record and terraces in the south piedmont of Lenglongling, Qilian Shan. Journal of Lanzhou University (Natural Version) 31, 102-110.

Grunert, J., Lehmkuhl, F. \& Walther, M. 2000: Palaeoclimatic evolution of the Uvs Nuur Basin and adjacent areas (Western Mongolia). Quaternary International 65/66, 171-192.

Haeberli, W., Bosch, H., Scherler, K., Ostrem, G. \& Wallen, C. C. 1989: World Glacier Inventory: Status 1988. Compiled by the World Glacier Monitoring Service, IAHS-UNEP-UNESCO, Wallingford, UK.

Heuberger, H. \& Sgibnev, V. V. 1998: Paleoglaciological studies in the Ala-Archa National Park, Kyrgystan, NW Tian-Shan mountains, and using multitextural analysis as a sedimentological tool for solving stratigraphic problems. Zeitschrift für Gletscherkunde und Glazialgeologie 34, 95-123.
Holmes, J. A. \& Street-Perrott, F. A. 1989: The Quaternary glacial history of Kashmir, north-west Himalaya: a revision of de Terra and Paterson's Sequence. Zeitschrift für Geomorphologie 76, $195-212$.

Hövermann, J., Hövermann, E. \& Lehmkuhl, F. 1998: Geomorphologische Untersuchungen im nördlichen Vorland des Qilian Shan, China. Berliner Geographische Abhandlungen 63, 99-119.

Hövermann, J. \& Lehmkuhl, F. 1994: Die vorzeitlichen Vergletscherungen in Ost- und Zentraltibet. Göttinger Geographische Abhandlungen 95, 71-114.

Hövermann, J., Lehmkuhl, F. \& Pörtge, K.-H. 1993a: Pleistocene glaciations in Eastern and Central Tibet - preliminary results of the Chinese-German joint expeditions. Zeitschrift für Geomorphologie 92, 85-96.

Hövermann, J., Lehmkuhl, F. \& Süssenberger, H. 1993b: Neue Befunde zur Paläoklimatologie Nordafrikas und Zentralasiens. Abhandlungen der Braunschweigischen Wissenschaftlichen Gesellschaft 43, 127-150.

Kang, J. 1992: Quaternary glacial evolution sequence in the south slope of Lenglongling of Qilian Mountains. Glaciology and Geocryology 14, 352-355.

Klinge, M. 2001: Glazialgeomorphologische Untersuchungen im Mongolischen Altai als Beitrag zur jungquartären Landschaftsund Klimageschichte der Westmongolei. Aachener Geographische Arbeiten 35, 125 pp.

Klinge, M., Böhner, J. \& Lehmkuhl, F. 2003: Climate patterns, snow- and timberline in the Altai Mountains, Central Asia. Erdkunde 57, 296-308.

Klinge, M. \& Lehmkuhl, F. 2004: Pleistocene glaciations in southern and eastern Tibet. In Ehlers, J. \& Gibbard, P. L. (eds.): Quaternary Glaciations - Extent and Chronologies, Part III: South America, Asia, Africa, Australia, Antarctica, 361-369. Elsevier, Amsterdam.

Klute, F. 1930: Verschiebung der Klimagebiete der letzten Eiszeit. Petermanns Geographische Mitteilungen, Ergänzungs-Heft 209, 166-182.

Kuhle, M. 1985: Glaciation research in the Himalayas: a new ice age theory. Universitas 27, 281-294.

Kuhle, M. 1986: The upper limit of glaciation in the Himalayas. GeoJournal 13, 331-346.

Kuhle, M. 1987: The problem of a Pleistocene inland glaciation of the northeastern Qinghai-Xizang Plateau. In Hövermann, J. \& Wenying, W. (eds.): Reports of the Qinghai-Xizang (Tibet) Plateau, 250-315. Science Press, Beijing.

Kuhle, M. 1988a: Geomorphological findings on the build-up of Pleistocene glaciation in Southern Tibet and on the problem of inland ice. GeoJournal 17, 457-512.

Kuhle, M. 1988b: Topography as a fundamental element of glacial systems. GeoJournal 17, 545-568.

Kuhle, M. 1990a: The cold deserts of high Asia (Tibet and contiguous mountains). GeoJournal 20, 319-323.

Kuhle, M. 1990b: Ice marginal ramps and alluvial fans in semiarid mountains: convergence and difference. In Rachocki, A. H. \& Church, M. (eds.): Alluvial Fans: a Field Approach, 55-68. Wiley \& Sons Ltd., Chichester.

Kuhle, M. 1991: Observations supporting the Pleistocene inland glaciation of High Asia. GeoJournal 25, 131-231.

Kuhle, M. 1993: A short report of the Tibet excursion 14-A. Part of the XIII INQUA Congress 1991 in Beijing. GeoJournal 29, 426-427.

Kuhle, M. 1995: Glacial isostatic uplift of Tibet as a consequence of a former ice sheet. GeoJournal 37, 431-449.

Lehmkuhl, F. 1992: Breitböden als glaziale Erosionsformen - Ein Bericht über Vergletscherungstypen im Qilian Shan und im Kunlun Shan (VR China). Zeitschrift für Gletscherkunde und Glazialgeologie 27/28, 51-62.

Lehmkuhl, F. 1995a: Geomorphologische Untersuchungen zum Klima des Holozäns und Jungpleistozäns Osttibets. Göttinger Geographische Abhandlungen 102, 1-184. 
Lehmkuhl, F. 1995b: Zum vorzeitlichen glazialen Formenschatz im zentralen Qilian Shan (Tulai Shan). Petermanns Geographische Mitteilungen 139, 239-251.

Lehmkuhl, F. 1997: Late Pleistocene, Late-glacial and Holocene glacier advances on the Tibetan Plateau. Quaternary International 38/39, 77-83.

Lehmkuhl, F. 1998a: Quaternary Glaciations in Central and Western Mongolia. In Owen, L. A. (ed.): Mountain Glaciations. Quaternary Proceedings 6, 153-167.

Lehmkuhl, F. 1998b: Extent and spatial distribution of Pleistocene glaciations in Eastern Tibet. Quaternary International 45/46, 123-134.

Lehmkuhl, F. 1999: Rezente und jungpleistozäne Formungs- und Prozeßregionen im Turgen-Kharkhiraa, Mongolischer Altai. Erde 130, 151-172.

Lehmkuhl, F. \& Haselein, F. 2000: Quaternary palaeoenvironmental change on the Tibetan Plateau and adjacent areas (Western China and Mongolia). Quaternary International 65/66, 121-145.

Lehmkuhl, F. \& Hövermann, J. E. 1996: Landscape and paleoclimatic evolution of the Tibetan Plateau. Die Geowissenschaften 7/8, 268-271.

Lehmkuhl, F., Klinge, M. \& Lang, A. 2002: Late Quaternary glacier advances, lake level fluctuations and aeolian sedimentation in Southern Tibet. Zeitschrift für Geomorphologie N.F. 126 , 183-218.

Lehmkuhl, F., Klinge, M., Rees-Jones, J. \& Rhodes, E. J. 2000: First luminescence dates for Late Quaternary aeolian sedimentation in Central and Eastern Tibet. Quaternary International 68/71, 117-132.

Lehmkuhl, F., Klinge, M. \& Stauch, G. 2004: The extent of Late Pleistocene Glaciations in the Altai and Khangai Mountains. In Ehlers, J. \& Gibbard, P. L. (eds.): Quaternary Glaciations - Extent and Chronologies. Part III: South America, Asia, Africa, Australia, Antarctica, 243-254. Elsevier, Amsterdam.

Lehmkuhl, F. \& Lang, A. 2001: Geomorphological investigations and luminescence dating in the southern part of the Khangay and the Valley of the Gobi Lakes (Central Mongolia). Journal of Quaternary Sciences 16, 69-87.

Lehmkuhl, F., Owen, L. A. \& Derbyshire, E. 1998: Late Quaternary glacial history of Northeastern Tibet. In Owen, L. A. (ed.): Mountain Glaciations. Quaternary Proceedings 6, 121-142.

Lehmkuhl, F. \& Rost, K. T. 1993: Zur pleistozaenen Vergletscherung Ostchinas und Nordosttibets. Petermanns Geographische Mitteilungen 137, 67-78.

Li, B., Li, J. \& Cui, Z. (eds.) 1991: Quaternary Glacial Distribution Map of Qinghai-Xizang (Tibet) Plateau 1:3,000,000. Scientific Advisor: Shi Yafeng. Quaternary Glacier, and Environment Research Center, Lanzhou University.

Li, J. \& Pan, B. 1989: Quaternary glaciation in the Dalijia Mountain on the northeast border of Qinghai-Xizang (Tibet) Plateau. International Field Workshop on Loess Geomorphological Processes and Hazards. May 25 to June 5, 1989. Journal of Lanzhou University, 101-108.

Li, S. \& Shi, Y. 1992: Glacial and lake fluctuations in the area of West Kunlun mountains during the last 45,000 years. Annals of Glaciology 16, 79-84.

Liu, Z., Jiao, S., Zhang, Y., Yi, S., Al, C., Zhao, Y., Li, Y., Wang, H., Xu, J., Hu, J. \& Guo, T. 1988: Geological Map of the Qinghai-Xizang (Tibet) Plateau and Adjacent Areas $(1: 1,500,000)$. Compiled chiefly by Chengdu Institute of Geology Resources, Chinese Academy of Geological Sciences, Supervisor: Liu Zengqian, Explanatory note, Chendu, 91 pp.

Lui, T., Zhao, X., Han, J. \& Zheng, H. (eds.) 1985: Loess and Environment. 251 pp. China Ocean Press, Beijing.

Mayewski, P. A. \& Jeschke, P. A. 1979: Himalayan and TransHimalayan glacier fluctuations since AD 1812. Arctic and Alpine Research 11, 267-287.

Mayewski, P. A., Pregent, G. P., Jeschke, P. A. \& Ahmad, N. 1980: Himalayan and Trans-Himalayan glacier fluctuations and the south Asian monsoon record. Arctic and Alpine Research 12, 171-182.

Molnar, P. \& England, P. 1990: Late Cenozoic uplift of mountain ranges and global climatic change: chicken or egg? Nature 346, 29-34.

Ono, Y., Shulmeister, J., Lehmkuhl, F., Asahi, K. \& Aoki, T. 2004: Timings and causes of glacial advances across the PEP-II transect (East-Asia to Antarctica) during the last glaciation cycle. Quaternary International 118/119, 55-68.

Owen, L. A., Bailey, R. M., Rhodes, E. J., Mitchell, W. A. \& Coxon, P. 1997: Style and timing of Glaciation in the Lahul Himalaya, northern India: a framework for reconstructing the late Quaternary palaeoclimatic change in the Western Himalayas. Journal of Quaternary Science 12, 83-109.

Owen, L. A., Derbyshire, E. \& Fort, M. 1998: The Quaternary glacial history of the Himalaya. In Owen, L. A. (ed.): Mountain Glaciations. Quaternary Proceedings 6, 91-120.

Owen, L. A., Finkel, R. C. \& Caffee, M. W. 2002a: A note on the extent of glaciation throughout the Himalaya during the global Last Glacial Maximum. Quaternary Science Reviews 21, 147-157.

Owen, L. A., Finkel, R. C., Caffee, M. W. \& Gualtieri, L. 2002b: Timing of multiple glaciations during the Late Quaternary in the Hunza Valley, Karakoram Mountains, Northern Pakistan: constrained by cosmogenic radionuclide dating of moraines. Geological Society of America Bulletin 114, 593-604.

Owen, L. A., Finkel, R. C., Ma, H., Spencer, J. Q., Derbyshire, E., Barnard, P. L. \& Caffee, M. W. 2003c: Timing and style of Late Quaternary glaciations in NE Tibet. Geological Society of America Bulletin 11, 1356-1364.

Owen, L. A., Gualtieri, L., Finkel, R. C., Caffee, M. W., Benn, D. I. \& Sharma, M. C. 2001: Cosmogenic radionuclide dating of glacial landforms in the Lahul Himalaya, Northern India: defining the timing of Late Quaternary glaciation. Journal of Quaternary Science 16, 555-565.

Owen, L. A., Kamp Jr, U., Spencer, J. Q. \& Haserodt, K. 2002c: Timing and style of Late Quaternary glaciation in the eastern Hindu Kush, Chitral, northern Pakistan: a review and revision of the glacial chronology based on new optically stimulated luminescence dating. Quaternary International 97/98, 41-56.

Owen, L. A. \& Lehmkuhl, F. (eds.) 2000: Late Quaternary Glaciation and Paleoclimate of the Tibetan Plateau and Bordering Mountains. Quaternary International 65/66, 212 pp.

Owen, L. A., Ma, H., Derbyshire, E., Spencer, J. Q., Barnard, P. L., Nian, Z. Y., Finkel, R. C. \& Caffee, M. W. 2003b: The timing and style of Late Quaternary glaciation in the La Ji Mountains, NE Tibet: evidence for restricted glaciation during the latter part of the Last Glacial. Zeitschrift für Geomorphologie 130, 263-276.

Owen, L. A., Spencer, J. Q., Ma, H., Barnard, P. L., Derbyshire, E., Finkel, R. C., Caffee, M. W. \& Nian, Z. Y. 2003a: Timing of Late Quaternary glaciation along the southwestern slopes of the Qilian Shan. Boreas 32, 281-291.

Owen, L. A., Teller, J. T. \& Rutter, N. W. 2002d: Glaciation and reorganization of Asia's network of drainage. Global and Planetary Change 30, 289-374.

Owen, L. A. \& Zhou, S. (eds.) 2002: Glaciation in Monsoon Asia. Quaternary International 97/98, 179 pp.

Owen, L. A. \& Benn, D. I. 2005: Equilibrium-line altitudes of the Last Glacial Maximum for the Himalaya and Tibet: an assessment and evaluation of results. Quaternary International (in press).

Owen, L. A., Finkel, R. C., Barnard, P. L., Ma, H., Asahi, K., Caffee, M. W. \& Derbyshire, E. 2005: Climatic and topographic controls on the style and timing of Late Quaternary glaciation throughout Tibet and the Himalaya defined by ${ }^{10} \mathrm{Be}$ cosmogenic radionuclide surface exposure dating. Quaternary Science Reviews (in press).

Pachur, H.-J., Wünnemann, B. \& Zhang, H. 1995: Lake evolution in the Tennger Desert, Northwestern China, during the last 40,000 years. Quaternary Research 44, 171-180. 
Phillips, W. M., Sloan, V. F., Shroder, J. F. Jr., Sharma, P., Clarke, M. L. \& Rendell, H. M. 2000: Asynchronous glaciation at Nanga Parbat, northwestern Himalaya Mountains, Pakistan. Geology 28, 431-434.

Porter, S. C., Singhvi, A., An, Z. \& Lai, Z. 2001: Luminescence age and palaeonvironmental implications of a Late Pleistocene ground wedge on the Northeastern Tibetan Plateau. Permafrost and Periglacial Processes 12, 203-210.

Prell, W. L. \& Kutzbach, J. F. 1992: Sensitivity of the Indian monsoon to forcing parameters and implications for its evolution. Nature 360, 647-652.

$\mathrm{Pu}$, Q. 1991: Quaternary glaciers in China. In Zhang, Z., Shao, S., Tong, G. \& Cao, J. (eds.): The Quaternary of China, 240-273. China Ocean Press, Beijing.

Qin, B. \& Yu, G. 1998: Implications of lake level variations at $6 \mathrm{ka}$ and $18 \mathrm{ka}$ in mainland China. Global and Planetary Change 18, $59-72$.

Richards, B. W. M., Benn, D., Owen, L. A., Rhodes, E. J. \& Spencer, J. Q. 2000b: Timing of Late Quaternary glaciations south of Mount Everest in the Khumbu Himal, Nepal. Geological Society of America Bulletin 112, 1621-1632.

Richards, B. W. M., Owen, L. A. \& Rhodes, E. J. 2000a: Timing of Late Quaternary glaciations in the Himalayas of northern Pakistan. Journal of Quaternary Science 15, 283-297.

Richardson, S. D. \& Reynolds, J. M. 2000: An overview of glacial hazards in the Himalayas. Quaternary International 65/66, $31-48$.

Rost, K. T. 1998: Geomorphologische und paläoklimatische Untersuchungen in zentralchinesischen Gebirgen und Gebirgsvorländern. Göttinger Geographische Abhandlungen 105, 1-168.

Rost, K. T. 2000: Pleistocene paleoenvironmental change in the high mountain ranges of central China and adjacent regions. Quaternary International 65/66, 147-160.

Röthlisberger, F. \& Geyh, M. A. 1985: Glacier variations in Himalayas and Karakoram. Zeitschrift für Gletscherkunde und Glazialgeologie 21, 237-249.

Ruddiman, W. F. \& Kutzbach, J. E. 1989: Forcing of Late Cenozoic Northern Hemisphere climate by plateau uplift in southern Asia and the America west. Journal of Geophysical Research 94, 409-427.

Rudoi, A. N. 2002: Glacier-dammed lakes and geological work of glacial superfloods in the Late Pleistocene, Southern Siberia, Altai Mountains. Quaternary International 87, 119-140.

Rutter, N. W. 1995: Problematic ice sheets. Quaternary International 28, 19-37.

Sarkar, A., Ramesh, R., Bhattacharya, S. K. \& Rajagopalan, G. 1990: Oxygen isotope evidence for a stronger winter monsoon current during the last glaciation. Nature 343, 549-551.

Schäfer, J. M. 2000: Reconstruction of Landscape Evolution and Continental Paleoglaciations Using in-situ Cosmogenic Nuclides: Examples from Antarctica and the Tibetan Plateau. Ph.D. dissertation, ETH Zürich, 153 pp.

Schäfer, J. M., Tschudi, S., Zhizhong, Z., Xihao, W., Ivy-Ochs, S., Wieler, R., Baur, H., Kubik, P. W. \& Schluchter, C. 2002: The limited influence of glaciations in Tibet on global climate over the past 170000 yr. Earth and Planetary Science Letters 194, 287-297.

Schlütz, F. 1999: Palynologische Untersuchungen über die holozäne Vegetations-, Klima- und Siedlungsgeschichte in Hochasien (Nanga Parbat, Karakorum, Nianbaoyeze, Lhasa) und das Pleistozän in China (Qinling-Gebirge, Gaxun Nur). Dissertationae Botanicae 315, 183 pp.

Sharma, M. C. \& Owen, L. A. 1996: Quaternary glacial history of the Garhwal Himalaya, India. Quaternary Science Reviews 15 , $335-365$.

Shi, Y. 1988: Map of Snow, Ice, and Frozen Ground in China. Compiled by Lanzhou Institute of Glaciology and Geocryology. 32 pp. and map. China Cartographic Publishing House, Beijing.

Shi, Y. 1992: Glaciers and glacial geomorphology in China. Zeitschrift für Geomorphologie 86, 51-63.
Shi, Y., Kong, Z., Wang, S., Tang, L., Wang, F., Yao, T., Zhao, X., Zhang, P. \& Shi, S. 1993: Mid-Holocene climates and environments in China. Global and Planetary Change 7, 219-233.

Shi, Y., Ren, B., Wang, J. \& Derbyshire, E. 1986: Quaternary Glaciation in China. Quaternary Science Reviews 5, 503-510.

Spencer, J. Q. \& Owen, L. A. 2004: Optically stimulated luminescence dating of Late Quaternary glaciogenic sediments in the upper Hunza valley: validating the timing of glaciation and assessing dating methods. Quaternary Sciences Reviews 23, $175-119$.

Spicer, R. A., Harris, N. B. W., Widdowson, M., Herman, A. B., Guo, S., Valdes, P. J., Wolfe, J. A. \& Kelley, S. P. 2003: Constant elevation of southern Tibet over the past 15 million years. Nature $42,622-624$.

Su, Z. \& Shi, Y. 2002: Response of monsoon temperate glaciers to global warming since the Little Ice Age. Quaternary International 97/98, 123-131.

Sun, J. \& Chen, Y. 1991: Palynological records of the last 11,000 years in China. Quaternary Science Reviews 10, 537-544.

Tarasov, P. E. \& Harrison, S. P. 1998: Lake status from the former Soviet Union and Mongolia: a continental-scale synthesis. Paläoklimaforschung/Palaeoclimate Research 25, 115-130.

Tarasov, P. E., Pushenko, M. Y., Harrison, S. P., Saarse, L., Andreev, A. A., Aleshinskaya, Z. V., Davydova, N. N., Dorofeyuk, N. I., Efremov, Yu. V., Elina, G. A., Elovicheva, Y. K., Filimonova, L. V., Gunova, V. S., Khomutova, V. I., Kvavadze, E. V., Neustreuva, I. Yu., Pisareva, V. V., Sevastyanov, D. V., Shelekhova, T. S., Subetto, D. A., Uspenskaya, O. N. \& Zernitskaya, V. P. 1996: Lake status records from the FSU. Database documentation Version 2. IGBP PAGES/World Data Center-A for Paleoclimatology Data Contribution Series \#96-032. NOAA/NGDC Paleoclimate Research 25, 115-130.

Taylor, P. J. \& Mitchell, W. A. 2000: Late Quaternary glacial history of the Zanskar Range, North-west Indian Himalaya. Quaternary International 65/66, 81-100.

Thompson, L. G., Mosley-Thompson, E., Davis, M. E., Bolzan, J. F., Dai, J., Yao, T., Gundestrup, N., Wu, X., Klein, L. \& Xie, Z. 1989: Holocene-Late Pleistocene climatic ice core records from Qinghai-Tibetan Plateau. Science 246, 474-477.

Thompson, L. G., Yao, T., Davis, M. E., Henderson, K. A., MosleyThompson, E., Lin, P. N., Beer, J., Synal, H., Cole-Dai, J. \& Bolzan, J. F. 1997: Tropical climate instability: the last glacial cycle from a Qinghai-Tibetan ice core. Science 276, 1821-1825.

Tsukamoto, S., Asdahi, K., Watanabe, T., Kondo, R. \& Rink, W. J. 2002: Timing of past glaciation in Kanchenjunga Himal, Nepal by optically stimulated luminescence dating of tills. Quaternary International 97/98, 57-67.

Wang, F. \& Fan, C. Y. 1987: Climatic changes in the QinghaiXizang (Tibetan) region of China during the Holocene. Quaternary Research 28, 50-60.

Wünnemann, B., Pachur, H.-J., Li, J. \& Zhang, H. 1998: Chronologie der pleistozänen und holozänen Seespiegelschwankungen des Gaxun Nur/Sogo Nur und Baijian Hu. Innere Mongolei, NW-China. Petermanns Geographische Mitteilungen 142, 191-206.

Yang, X. 1991: Geomorphologische Untersuchungen in Trockenräumen NW-Chinas unter besonderer Berücksichtigung von Badanjilin und Takelamagan. Göttinger Geographische Abhandlungen 96, 1-124.

Yang, X., Hu, Z., Jäkel, D., Owen, L. A. \& Han, J. 2002: Late Quaternary paleoenvironment change and landscape evolution along the Keriya River, Xinjiang, China: the relationship between high mountain glaciation and landscape evolution in foreland desert regions. Quaternary International 97/98, $155-166$.

Zech, W., Bäumler, R., Sovoskul, O. \& Sauer, G. 1996: Zur Problematik der pleistozänen und holozänen Vergletscherung 
des Westlichen Tienshan. Eiszeitalter und Gegenwart 46 , 144-151.

Zech, W., Glaser, B., Abramowski, U., Dittmar, C. \& Kubik, P. W. 2003: Reconstruction of the Late Quaternary Glaciation of the Macha Khola valley (Gorkha Himal, Nepal) using relative and absolute $\left({ }^{14} \mathrm{C},{ }^{10} \mathrm{Be}\right.$, dendrochronology) dating techniques. Quaternary Science Reviews 22, 2253-2265.

Zech, W., Glaser, B., Ni, A., Petrov, M. \& Lemzin, I. 2000: Soil as indicators of the Pleistocene and Holocene landscape history: Alay Range (Khyrgstan). Quaternary International 65/66, 161-170.

Zeitler, P. K., Meltzer, A. S., Koons, P. O., Craw, D., Hallet, B., Chamberlain, C. P., Kidd, W. S. F., Park, S. K., Seeber, L., Bishop, M. \& Shroder, J. 2001: Erosion, Himalayan geodynamics, and the geomorphology of metamorphism. Geological Society of America Today 11, 4-9.
Zhang, Z., Shao, S. \& Liu, H. 1991: Quaternary stratigraphy in China. In Zhang, Z., Shao, S., Tong, G. \& Cao, J. (eds.): The Quaternary of China, 77-121. China Ocean Press, Beijing.

Zhen, S. \& Shi, Y. 2002: Response of monsoonal temperate glaciers to global warming since the Little Ice Age. Quaternary International 97/98, 123-131.

Zheng, B. 1989: Controversy regarding the existence of a large ice sheet on the Qinghai-Xizang (Tibetan) Plateau during the Quaternary Period. Quaternary Research 32, 121-123.

Zheng, B. \& Rutter, N. 1998: On the problem of Quaternary glaciations, and the extent and patterns of Pleistocene ice cover in the Qinghai-Xizang (Tibet) plateau. Quaternary International 45/ 46, 109-122.

Zhou, S. \& Li, J. 1998: The sequence of Quaternary glaciation in the Bayan Har Mountains. Quaternary International 45/46, 135-142. 